Boston University School of Law

Scholarly Commons at Boston University School of Law

Faculty Scholarship

2020

\title{
Brief of Amici Curiae Legal Scholars in Support of Equality in Support of Respondents, Fulton v. City of Philadelpha
}

Kyle Velte

University of Kansas

David Cruz

University of Southern California Law

Michael Higdon

University of Tennessee, Knoxville

Anthony Michael Kreis

Georgia State University College of Law

Shirley Lin

New York University

Follow this and additional works at: https://scholarship.law.bu.edu/faculty_scholarship See next page for additional authors

Part of the Civil Rights and Discrimination Commons, First Amendment Commons, Law and Race

Commons, Religion Law Commons, and the Sexuality and the Law Commons

\section{Recommended Citation}

Kyle Velte, David Cruz, Michael Higdon, Anthony Michael Kreis, Shirley Lin \& Linda C. McClain, Brief of Amici Curiae Legal Scholars in Support of Equality in Support of Respondents, Fulton v. City of

Philadelpha, (2020).

Available at: https://scholarship.law.bu.edu/faculty_scholarship/1027

This Brief is brought to you for free and open access by Scholarly Commons at Boston University School of Law. It has been accepted for inclusion in Faculty Scholarship by an authorized administrator of Scholarly Commons at Boston University School of Law. For more information, please contact lawlessa@bu.edu. 


\section{Authors}

Kyle Velte, David Cruz, Michael Higdon, Anthony Michael Kreis, Shirley Lin, and Linda C. McClain 
No. 19-123

\title{
$\mathfrak{J n} \mathfrak{T h e}$ Wupreme Court of the ofnited States
}

SHARONELL FULTON, et al.,

Petitioners,

v.

CITY OF PHILADELPHIA, et al.,

Respondents.

\section{On Writ Of Certiorari To The United States Court Of Appeals For The Third Circuit}

\section{BRIEF OF AMICI CURIAE LEGAL SCHOLARS IN SUPPORT OF EQUALITY IN SUPPORT OF RESPONDENTS} \\ Kyle C. Velte \\ Associate Professor \\ Counsel of Record \\ UNIVERSITY OF KANSAS \\ SCHOOL OF LAW \\ 1535 W. 15th St. \\ Lawrence, KS 66045 \\ (720) 648-9266 \\ kvelte@ku.edu \\ DAVID B. CRUZ \\ Newton Professor of \\ Constitutional Law \\ UNIVERSITY OF SOUTHERN \\ CALIFORNIA \\ GOULD SCHOOL OF LAW \\ 699 Exposition Blvd. \\ Los Angeles, CA 90089 \\ MichAEL J. HigdON \\ Associate Dean for Faculty \\ Development and \\ Professor of Law \\ UNIVERSITY OF TENNESSEE \\ COLLEGE OF LAW \\ 1505 W. Cumberland Avenue \\ Knoxville, TN 37996 \\ ClifFord S. DAVIDSON \\ SNELl \& WILMER \\ One Centerpointe Dr. \\ Lake Oswego, OR 97035 \\ 503-624-6800 \\ csdavidson@swlaw.com \\ KeLLY H. Dove \\ SNELL \& WILMER \\ 3883 Howard Hughes Pkwy., \\ Suite 1100 \\ Las Vegas, NV 89169 \\ 702-784-5286 \\ kdove@swlaw.com \\ SHIRLEY LIN \\ Acting Assistant Professor \\ NEW YORK UNIVERSITY \\ SCHOOL OF LAW \\ 40 Washington Sq. South \\ New York, NY 10012
}

[Additional Counsel Listed On Inside Cover]

COCKLE LEGAL BRIEFS (800) 225-6964

WWW.COCKLELEGALBRIEFS.COM 
Anthony Michael KReIS

Assistant Professor GeORGIA State UNIVERSITY

COLLEGE OF LAW

85 Park Place NE, Room 314

Atlanta, GA 30303
LINDA C. MCCLAIN

Robert Kent Professor of Law

Boston UNIVERSITY

SCHOOL OF LAW

765 Commonwealth Avenue

Boston, MA 02215 
TABLE OF CONTENTS

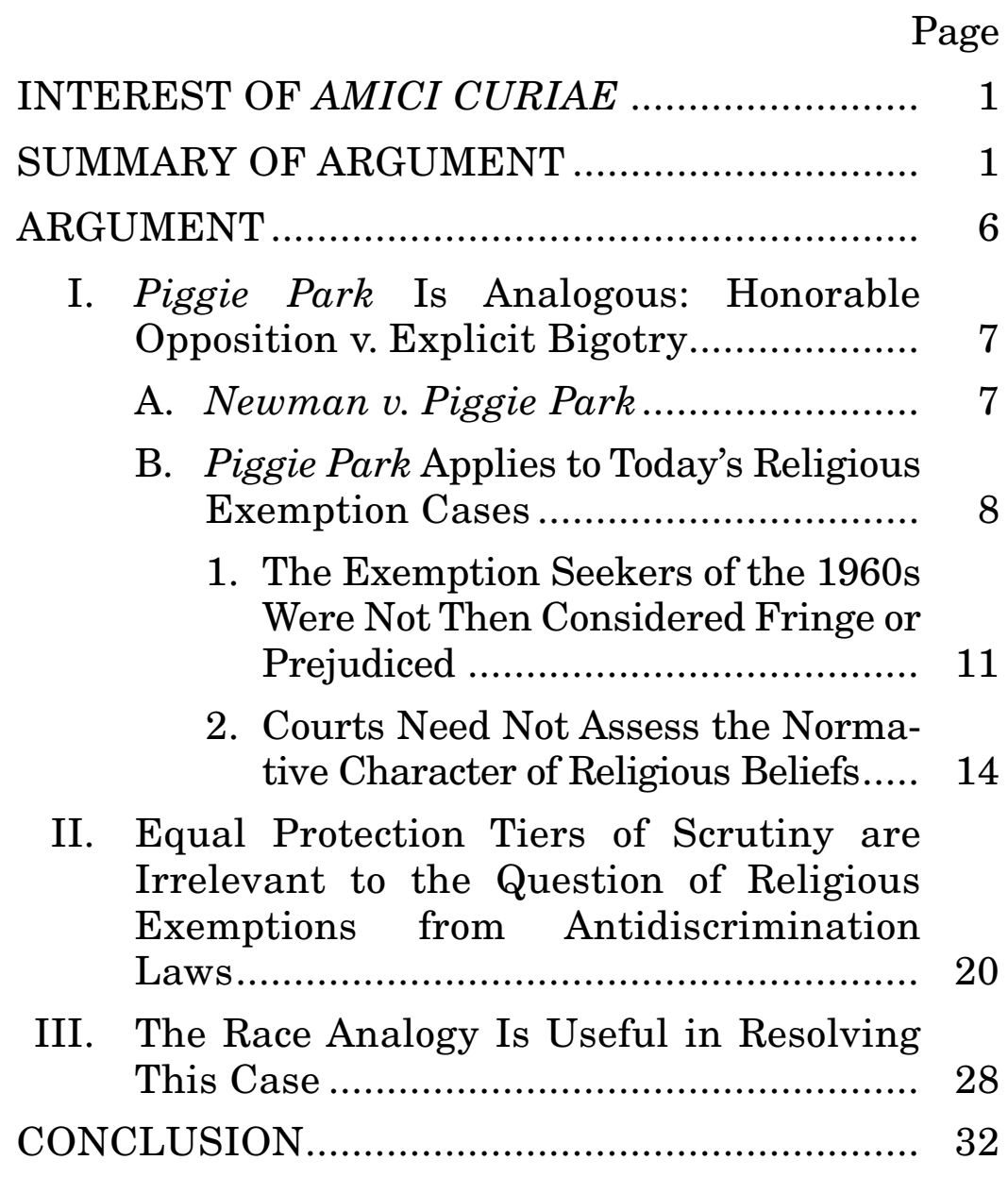




\section{TABLE OF AUTHORITIES}

Page

Federal CASeS

Bostock v. Clayton County, 140 S. Ct. 1731 (2020) .....................................passim

Burwell v. Hobby Lobby Stores, Inc., 573 U.S. 682 (2014)

City of Los Angeles v. Manhart, 435 U.S. 702 (1978)

County of Allegheny v. ACLU, 492 U.S. 573 (1989)

Employment Division v. Smith, 494 U.S. 872 (1990)

Hurley v. Irish-Am. Gay, Lesbian \& Bisexual Group of Bos., 515 U.S. 557 (1995)

Karnoski v. Trump, 926 F.3d 1180 (9th Cir. 2019)

Latta v. Otter, 771 F.3d 456 (9th Cir. 2014) 22,23

Lyng v. Nw. Indian Cemetery, 485 U.S. 439 (1987)

Masterpiece Cakeshop, Ltd. v. Colo. Civil Rights Comm'n, 138 S. Ct. 1719 (2018) passim

Newman v. Piggie Park Enters., Inc., 390 U.S. 400 (1968), rev'd, 377 F.2d 433 (4th Cir. 1967), aff'd, 390 U.S. 400 (1968) ......passim 
iii

TABLE OF AUTHORITIES-Continued

Page

Obergefell v. Hodges, 135 S. Ct. 2584 (2015) ................................... 9, 10, 11

Roberts v. U.S. Jaycees, 468 U.S. 609 (1984)

$23,25,29,32$

Romer v. Evans,

517 U.S. 620 (1996)

SmithKline Beecham Corp. v. Abbott Labs, 740 F.3d 471 (9th Cir. 2014)

Thomas v. Review Bd. of the

Indiana Emp't Sec. Div., 450 U.S. 707 (1981)

United States v. Lee, 455 U.S. 252 (1982)

United States v. Virginia, 518 U.S. 515 (1996)

United States v. Windsor, 570 U.S. 744 (2013)

Windsor v. United States, 699 F.3d 169 (2d Cir. 2012), aff'd, 570 U.S. 744 (2013)

State Cases

Elane Photography, LLC v. Willock, 309 P.3d 53 (N.M. 2013)

Federal Statutes

42 U.S.C. $\S 2000 \mathrm{e}-2(\mathrm{a})(1)$ 
TABLE OF AUTHORITIES-Continued

Page

STATe StatuTES

Philadelphia Code § 9-1106

OTHER AUTHORITIES

Carlos A. Ball, Against LGBT Exceptionalism in Religious Exemptions from Antidiscrimination Obligations, 31 J. C.R. \& Econ. DEv. 233 (2018) passim

Dale M. Schowengerdt, Note, Defending Marriage: A Litigation Strategy to Oppose Same-Sex "Marriage", 14 REgENT U. L. REV. 487 (2002)

David B. Cruz, Piety and Prejudice: Free Exercise Exemption from Laws Prohibiting Sexual Orientation Discrimination, 69 N.Y.U. L. REV. 1176 (1994)

Deborah A. Widiss, Intimate Liberties and Antidiscrimination Law, 97 B.U. L. REV. 2083 (2017)

Douglas NeJaime \& Reva B. Siegel, Conscience Wars: Complicity-Based Conscience Claims in Religion and Politics, 124 YALE L.J. 2516 (2015)

Douglas NeJaime, Bigotry in Time: Race, Sexual Orientation, and Gender, 99 B.U. L. REV. 2651 (2019)

Elizabeth Sepper, Free Exercise Lochnerism, 115 Colum. L. REv. 1453 (2015) 
TABLE OF AUTHORITIES—Continued

Page

Elizabeth Sepper, Gays in the Moralized Marketplace, 7 Ala. C.R. \& C.L. L. REV. 129 (2015)

Frank Newport, For First Time, Majority of Americans Favor Legal Gay Marriage, GalluP (May 20, 2011)

James M. Oleske, Jr., The Evolution of Accommodations: Comparing the Unequal Treatment of Religious Objections to Interracial and Same-Sex Marriages, 50 HARV. C.R.-C.L.

L. REV. 99 (2015) $12,13,14$

Jeffrey M. Jones, Record-High 86\% Approve of Black-White Marriages, GALluP (Sept. 12, 2011)

Kyle C. Velte, All Fall Down: A Comprehensive Approach to Defeating the Religious Right's Challenge to Anti-Discrimination Statutes, 49 ConN. L. REv. 1 (2016)

Kyle C. Velte, Fueling the Terrorist Fires with the First Amendment: Religious Freedom, the Anti-LGBT Right, and Interest Convergence Theory, 82 BRoOKLYN L. REV. 1109 (2017).................1

Kyle C. Velte, Restoring the Race Analogy in LGBT Religious Exemption Cases, 42 Cardozo L. REv. (forthcoming 2020). .1 
TABLE OF AUTHORITIES-Continued

Page

Kyle C. Velte, Why the Religious Right Can't Have Its (Straight Wedding) Cake and Eat It Too: Breaking the Preservation-ThroughTransformation Dynamic in Masterpiece Cakeshop v. Colorado Civil Rights Commission, 36 LAW \& INEQUALITY (forthcoming 2018)..........1

Lawrence G. Sager \& Nelson Tebbe, The Reality Principle, 34 Const. Comment. 171 (2019) ......17, 29

Linda C. McClain, The Civil Rights Act of 1964 and "Legislating Morality": On Conscience, Prejudice, and Whether "Stateways" can Change "Folkways," 95 B.U. L. REv. 891 (2015) ...... 10, 12, 19

Linda C. McClain, Who's the Bigot?: Learning FRoM Conflicts OVER MARRIAGe AND Civil RIGHTS LAW 3 (Oxford University Press 2020) passim

Lynn D. Wardle \& Lincoln C. Oliphant, In Praise of Loving: Reflections on the "Loving Analogy" for Same-Sex Marriage, 51 How. L.J. 117 (2007) $10,22,23$

Lynn D. Wardle, A Critical Analysis of Constitutional Claims for Same-Sex Marriage, 1996 BYU L. REV. 1 (1996)

Margaret M. Russell, Lesbian, Gay and Bisexual Rights and "The Civil Rights Agenda", 1 AFR.AM. L. \& PoL'Y REP. 33 (1994)

Mark Strasser, Public Policy, Same-Sex Marriage, and Exemptions for Matters of Conscience, 12 Fla. Coastal L. Rev. 135 (2010) 
vii

TABLE OF AUTHORITIES-Continued

Page

Michael Kent Curtis, A Unique Religious Exemption from Antidiscrimination Laws in the Case of Gays? Putting the Call for Those Who Discriminate Against Married or Marrying Gays in Context, 47 WAKe Forest L. REv. 173 (2012) $13,14,15$

Nelson Tebbe, Reply: Conscience and Equality, 31 J. C.R. \& ECON. DEv. 1 (2018) .

Patrick J. Borchers, Baker v. General Motors: Implications for Interjurisdictional Recognition of Non-Traditional Marriages, 32 CREIGHTON L. REV. 147 (1998)

Paul Baker, Note, Religious Exemptions and the Vocational Dimension of Work, 119 CoLUM. L. REV. 169 (2019)

Randall Kennedy, Marriage and the Struggle for Gay, Lesbian, and Black Liberation, 2005 UTAH L. REv. 781 (2005)

Robert H. Bork, The Judge's Role in Law and Culture, 1 Ave MaRIA L. Rev. 19 (2003)..................... 7

Robin Fretwell Wilson, Matters of Conscience: Lessons for Same-Sex Marriage from the Healthcare Context in SAME-SEX MARRIAGE AND Religious LiberTy: EMERging Conflicts 101 (Douglas Laycock et al. eds., 2008) .10

Ryan T. Anderson, Disagreement Is Not Always Discrimination: Masterpiece Cakeshop and the Analogy to Interracial Marriage, 16 GEO. J. L. \& PUB. PoL'Y 123 (2018) 
viii

TABLE OF AUTHORITIES—Continued

Page

Samuel J. Levine, Rethinking the Supreme Court's Hands-Off Approach to Questions of Religious Practice and Belief, 25 FORDHAM URB. L. J. 85 (1997)

Shannon Gilreath \& Arley Ward, Same-Sex Marriage, Religious Accommodation, and the Race Analogy, 41 VT. L. REv. 237 (2016) ..........12, 13

Thomas C. Berg, What Same-Sex-Marriage and Religious-Liberty Claims Have in Common, 5 Nw. J.L. \& Soc. PoL'Y 206 (2010) .............................7

Truman Opposes Biracial Marriage, N.Y. Times, Sept. 12, 1963, p. 30 ..............................................13 


\section{INTEREST OF AMICI CURIAE ${ }^{1}$}

Amici are law professors who focus on LGBT rights and antidiscrimination law in their scholarship and/or teaching. Kyle Velte is the author of several law review articles about the issues presented in this case, including a forthcoming article on which this brief is based. ${ }^{2}$

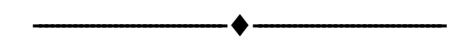

\section{SUMMARY OF ARGUMENT}

For 150 years, our country has grappled with the tension between its commitment to antidiscrimination principles, grounded in the Reconstruction Amendments, and its commitment to religious liberty,

${ }^{1}$ Respondents have filed blanket consents to the filing of amicus briefs. Amici requested and received consent from Petitioners and Intervenors. Counsel for a party has not authored the brief in whole or in part; nor has such counsel or a party made a monetary contribution intended to fund the preparation or submission of the brief.

${ }^{2}$ See Kyle C. Velte, Restoring the Race Analogy in LGBT Religious Exemption Cases, 42 CARDOZO L. REV. (forthcoming 2020), https://papers.ssrn.com/sol3/papers.cfm?abstract_id=3549952; see also Kyle C. Velte, Why the Religious Right Can't Have Its (Straight Wedding) Cake and Eat It Too: Breaking the Preservation-Through-Transformation Dynamic in Masterpiece Cakeshop v. Colorado Civil Rights Commission, 36 L. \& INEQ. 67 (2018); Kyle C. Velte, Fueling the Terrorist Fires with the First Amendment: Religious Freedom, the Anti-LGBT Right, and Interest Convergence Theory, 82 BROOK. L. REV. 1109 (2017); Kyle C. Velte, All Fall Down: A Comprehensive Approach to Defeating the Religious Right's Challenge to Anti-Discrimination Statutes, 49 ConN. L. REV. 1 (2016). 
grounded in the First Amendment. ${ }^{3}$ The national reckoning with requests for religious exemptions from antidiscrimination laws concerning race is now settled. From those legal battles emerged "time-tested, reasonable, and workable" ${ }^{4}$ balances. But this Court has not yet settled how religiously-grounded requests for exemptions from antidiscrimination laws concerning sexual orientation apply to those laws, as this Court's treatment of sexual orientation under the Constitution, like those antidiscrimination laws themselves, are of recent vintage. Yet, this Court's prior resolution of claims for religious exemptions from race antidiscrimination laws provide this Court a "reasonable, and workable" resolution of claims for religious exemptions from sexual orientation antidiscrimination laws.

This brief explains how this Court's treatment of race guides it to fashion the best decision-one that avoids normative critiques of who is supposedly virtuous or prejudiced. Constitutional law has no business singling out and assessing the normative or moral worthiness of religious beliefs vis-à-vis objections to antidiscrimination law if it does not also assess the normative or moral worthiness of other, non-religious objections to antidiscrimination law. Moreover, this

${ }^{3}$ See Carlos A. Ball, Against LGBT Exceptionalism in Religious Exemptions from Antidiscrimination Obligations, 31 J. C.R. \& ECON. DEv. 233, 237-38 (2018); see also Masterpiece Cakeshop, Ltd. v. Colo. Civil Rights Comm'n, 138 S. Ct. 1719, 1724 (2018); Roberts v. U.S. Jaycees, 468 U.S. 609, 623-24 (1984); Newman v. Piggie Park Enters., Inc., 390 U.S. 400, 402 n.5 (1968) (per curiam).

${ }^{4}$ Ball, supra note 3 , at 238. 
Court's teachings in cases about reconciling free exercise with antidiscrimination principles vis-à-vis race should lead to a harmonious, stable, and consistent doctrinal framework.

The Court's recent teachings in this vein provide an analytic framework for this case. Here, Philadelphia's Catholic Social Services ("CSS") claims a religious exemption from the Philadelphia Fair Practices Ordinance ("FPO"), which requires social service agencies contracting with it to serve adopting couples without discrimination, including same-sex couples. In Masterpiece Cakeshop, ${ }^{5}$ this Court left open the question of whether an analogy to race is appropriate in religious exemption cases involving sexual orientation. The race analogy in sexual orientation cases proceeds as follows: advocates and judges widely agree that courts should, and would, reject a religious exemption claim by a public accommodation-such as a wedding vendor or, as here, a foster care agency-seeking to turn away an African-American or interracial couple based on the public accommodation's religious beliefs that Blacks are inferior to whites or that the races should not mix. ${ }^{6}$ Analogizing to race means that courts should likewise reject CSS's religious exemption

${ }^{5} 138 \mathrm{~S}$. Ct. at 1732 (reversing on the basis that the Colorado Civil Rights Commission's treatment of baker was inconsistent with the neutrality the Free Exercise Clause requires).

${ }^{6}$ See Transcript of Oral argument at 21:16-22:9, Masterpiece Cakeshop, 138 S. Ct. 1719 (No. 16-111) [hereinafter Transcript]. By citing Piggie Park in the majority decision, the Court suggests that the race analogy is proper in sexual orientation religious exemption cases. See Masterpiece Cakeshop, 138 S. Ct. at 1727. 
claims seeking to turn away same-sex couples based on their religious beliefs about marriage.

Masterpiece Cakeshop cited this Court's 1968 decision in Newman v. Piggie Park Enters., Inc., ${ }^{7}$ thus applying the race analogy to sexual orientation cases. ${ }^{8}$ In the context of resolving the question of the proper standard for an award of attorneys' fees under the Civil Rights Act of 1964, Piggie Park affirmed the lower courts' rejection of a religious exemption claim in the context of race discrimination. ${ }^{9}$ Because today's exemption seekers make similar claims vis-à-vis sexual orientation discrimination, LGBT-rights advocates argue that Piggie Park resolves the question of religious exemptions against exemption seekers.

Yet today's exemption seekers reject use of the race analogy and the applicability of Piggie Park for at least two reasons. The first is based on a normative argument: The vendors of the 1960s who relied on their religious beliefs to discriminate based on race were racists, whereas today's exemption seekers are people of faith asserting honorable and sincere religious beliefs. Because they are not bigots and the long-ago vendors in Piggie Park were, they argue that the race analogy must fail. Otherwise, they contend, today's

\footnotetext{
7390 U.S. 400 (1968)

8138 S. Ct. at 1727.

${ }^{9} 390$ U.S. at 402 n.5.
} 
exemption seekers will be unfairly branded as bigots. ${ }^{10}$ Second, today's exemption seekers contend that the race analogy fails because race discrimination receives strict scrutiny, whereas this Court has not applied that standard to sexual orientation discrimination. ${ }^{11}$

These objections to the race analogy fail as a matter of historical and contemporary fact, and as a matter of law. The first objection fails because the race analogy and the honorableness of today's exemption seekers are not mutually exclusive. Opposition to religious exemptions need not entail any argument that exemption seekers are acting dishonorably or with animus, nor rest on the doctrine of Romer v. Evans ${ }^{12}$ or United States $v$. Windsor ${ }^{13}$ which struck down laws because they rested on anti-LGBT animus. To understand why the race analogy need not be a normative rebuke to today's exemption seekers, it is important to reappraise the relevant legal and factual premises. Below, amici frame this dispute constructively and neutrally, arguing that (1) exemption seekers' First Amendment claims fail as a matter of well-established law, regardless of the normative characterization of the asserted

10 See Linda C. McClain, Who's the Bigot?: LeARning FROM CONFLICTS OVER MARRIAGE AND CIVIL RIGHTS LAW 3 (2020) [hereinafter MCClAIN, WHO'S THE BigOT?].

11 The Court's recent decision in Bostock v. Clayton County, 140 S. Ct. 1731 (2020), strongly suggests that sexual orientation merits intermediate scrutiny, as does sex discrimination. See infra Part II.

12517 U.S. 620 (1996).

13570 U.S. 744 (2013). 
religious beliefs, and not because of anything normatively flawed about them; (2) the exemption seekers of the 1960s were viewed as honorable and sincere by courts and the public alike; and (3) courts must not look behind the asserted religious belief to validate or critique it, but must instead accept the asserted belief at face value.

From these premises, the normative characterization of the asserted religious belief-whether as animusdriven and framed as prejudiced, or as honorable as validating important and worthy norms-is irrelevant when assessing the propriety of the race analogy. Instead, the correct constitutional analysis begins with the premise that exemption seekers like CSS need not be viewed as inflected with animus or bigotry and that the race analogy and Piggie Park are properly used to analyze their claims. Similarly, the second objection-concerning strict scrutiny-fails because it is based on a fundamental misunderstanding of two things that are not commensurate: the relationship between the equal protection tiers of scrutiny, on one hand, and claims for religious exemptions from antidiscrimination law, on the other. Revealing these conceptual traps allows this Court to develop sounder and more coherent and consistent doctrine.

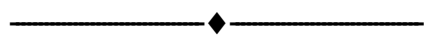

\section{ARGUMENT}

Supporters of today's religious exemptions seekers argue that race is different from sexual orientation, 
rendering the race analogy and Piggie Park inapposite. ${ }^{14}$ Their two central arguments against the race analogy fail, as explained below.

\section{Piggie Park Is Analogous: Honorable Oppo- sition v. Explicit Bigotry}

\section{A. Newman v. Piggie Park}

Piggie Park is at the heart of the dispute over the race analogy in the sexual orientation discrimination religious exemption cases. In 1964, soon after the Civil Rights Act (CRA) became law, African-Americans in South Carolina brought a class action alleging that the Piggie Park chain of BBQ restaurants refused them service on the same terms as white customers. ${ }^{15}$ The defendants - the corporate entity of Piggie Park Enterprises, Inc., and its principal shareholder and manager,

${ }^{14}$ See, e.g., Thomas C. Berg, What Same-Sex-Marriage and Religious-Liberty Claims Have in Common, 5 Nw. J.L. \& Soc. PoL'Y 206, 235 (2010); Patrick J. Borchers, Baker v. General Motors: Implications for Interjurisdictional Recognition of NonTraditional Marriages, 32 CREIGHTON L. REV. 147, 151-52 (1998); Robert H. Bork, The Judge's Role in Law and Culture, 1 AvE MARIA L. Rev. 19, 26 (2003); David Orgon Coolidge, Playing the Loving Card: Same-Sex Marriage and the Politics of Analogy, 12 BYU J. Pub. L. 201, 204 (1998); Dale M. Schowengerdt, Note, Defending Marriage: A Litigation Strategy to Oppose Same-Sex "Marriage”, 14 REGENT U.L. REV. 487, 491-92 (2002); Lynn D. Wardle, A Critical Analysis of Constitutional Claims for Same-Sex Marriage, 1996 BYU L. REV. 1, 75-82 (1996); see also Transcript, supra note 6, at 31:23-33:11.

${ }_{15}$ Newman v. Piggie Park Enters., Inc., 256 F. Supp. 941, 943-44 (D.S.C. 1966), rev'd, 377 F.2d 433 (4th Cir. 1967), aff'd, 390 U.S. 400 (1968) (per curiam). 
Maurice Bessinger-argued that they were exempt from complying with the CRA because it violated Bessinger's First Amendment right to freedom of religion because his faith "'compel[led] him to oppose any integration of the races whatever." "16 In a four-paragraph per curiam decision, this Court rejected a subjective standard for attorney fees under the CRA. ${ }^{17}$ In a footnote, the Court noted that, on remand, an award of attorney fees to the plaintiffs would be proper: "Indeed, this is not . . . even a borderline case, for the respondents interposed defenses so patently frivolous that a denial of counsel fees to the petitioners would be manifestly inequitable." 18 The Court pointed to the defendants' argument that the CRA "was invalid because it 'contravenes the will of God' and constitutes an interference with the 'free exercise of the Defendant's religion" as an example of a "patently frivolous" defense properly subject to an award of attorney fees. ${ }^{19}$

\section{B. Piggie Park Applies to Today's Religious Exemption Cases}

Today's exemption seekers argue what while the religious argument asserted in Piggie Park was deemed "frivolous," ${ }^{20}$ the religious beliefs of public

${ }^{16}$ Id.at 944.

17 Piggie Park, 390 U.S. at 401.

${ }^{18} \mathrm{Id}$. at 402 n.5.

${ }^{19}$ Id. (quoting Piggie Park, 377 F.2d 433 at 437-38 (Winter, J., concurring)).

${ }^{20}$ Piggie Park, 377 F.2d at 437 (Winters, J., concurring). 
accommodation such as CSS are just the oppositesincerely held. ${ }^{21}$ At the Masterpiece Cakeshop oral argument, Chief Justice Roberts addressed this particular concern:

[T] he racial analogy obviously is very compelling, but when the Court upheld same-sex marriage in Obergefell, it went out of its way to talk about the decent and honorable people who may have opposing views.

And to immediately lump them in the same group as people who are opposed to equality in relations with respect to race, I'm not sure that takes full account of that-of that concept in the Obergefell decision. ${ }^{22}$

Today's exemption seekers understandably seek to elevate this concern into an analytic frame that can avoid the race analogy. They scaffold their distinction of Piggie Park with language from Obergefell: "Many who deem same-sex marriage to be wrong reach that conclusion based on decent and honorable religious or philosophical premises, and neither they nor their beliefs are disparaged here. ${ }^{\prime 23}$ Overlaying this language

${ }^{21}$ See, e.g., Brief of Amicus Curiae Christian Business Owners Supporting Religious Freedom in Support of Petitioners at 30-31, Masterpiece Cakeshop v. Colo. Civil Rights Comm'n, 138 S. Ct. 1719 (2018) (No. 16-111), 2017 WL 4005666, at *30-31; see also MCClain, Who's THE BIGOT?, supra note 10, at 196-98; Douglas NeJaime, Bigotry in Time: Race, Sexual Orientation, and Gender, 99 B.U. L. REV. 2651, 2655 (2019).

${ }^{22}$ Transcript, supra note 6, 75:17-76:5.-74:3.

${ }^{23}$ Obergefell v. Hodges, 135 S. Ct. 2584, 2602 (2015); see also Douglas NeJaime \& Reva B. Siegel, Conscience Wars: 
from Obergefell upon the distinction they argue from Piggie Park's "patently frivolous" finding, today's exemption seekers argue that it is unfair and offensive to compare them to the racist vendors who claimed religious exemptions from the CRA. ${ }^{24}$ They insist that "race is different ... because essentially all religious actors who believe it is proper to make racial distinctions always act in bad faith (i.e., they are racists). On the other hand, it is argued, many of those who, on conscience grounds, believe it is proper to make distinctions on the basis of sexual orientation, in particular when it comes to marriage, act in good faith (i.e., they are not homophobic).”25

Complicity-Based Conscience Claims in Religion and Politics, 124 YALE L.J. 2516, 2558-66 (2015).

${ }^{24}$ See, e.g., Ryan T. Anderson, Disagreement Is Not Always Discrimination: Masterpiece Cakeshop and the Analogy to Interracial Marriage, 16 GEO. J. L. \& PUB. POL’Y 123, 134 (2018); Linda C. McClain, The Civil Rights Act of 1964 and "Legislating Morality": On Conscience, Prejudice, and Whether "Stateways" can Change "Folkways," 95 B.U. L. REV. 891, 894-95 (2015) [hereinafter McClain, Stateways].

${ }_{25}$ Ball, supra note 3, at 239-40. For example, Robin Wilson contends that " $[t]$ he religious and moral convictions that motivate objectors to refuse to facilitate same-sex marriage simply cannot be marshaled to justify racial discrimination." Robin Fretwell Wilson, Matters of Conscience: Lessons for Same-Sex Marriage from the Healthcare Context in SAME-SEX MARRIAGE AND RELIGIOUS LIBERTY: EMERGING CONFLICTS 101 (Douglas Laycock et al. eds., 2008). Lynn Wardle and Lincoln Oliphant contend that accepting the race analogy "means that those who oppose same-sex marriage are, like those who opposed inter-racial marriage, simply bigots." Lynn D. Wardle \& Lincoln C. Oliphant, In Praise of Loving: Reflections on the "Loving Analogy" for Same-Sex Marriage, 51 How. L.J. 117, 151 (2007). 
While the exemption seekers understandably disclaim animus, they seek to elevate these normative distinctions grounded in subjective moral judgments to a legal principle that excludes use of the race analogy. Deeper analysis of the bigoted versus honorable distinction, however, disrupts any potential persuasive work that might be accomplished with the exemption seekers' argument.

As an initial matter, it is important to address the exemption seekers' reliance on the Court's statement in Obergefell; considering that statement in context weakens its power as scaffolding. That portion of the opinion was immediately followed by another, contrasting statement that privileges and respects a different, pro-equality view: "But when that sincere, personal opposition becomes enacted law and public policy, the necessary consequence is to put the imprimatur of the State itself on an exclusion that soon demeans or stigmatizes those whose own liberty is then denied." ${ }^{26}$

\section{The Exemption Seekers of the 1960s Were Not Considered Fringe or Prej- udiced}

The distinction between "bigoted" and "honorable"

citizens in this context is simplistic and wrong as a matter of historical fact regarding how American

${ }^{26}$ Obergefell, 135 S. Ct. at 2602. 
society viewed these questions 50 years ago. ${ }^{27}$ Opponents of the CRA made religiously-grounded arguments similar to the arguments of today's exemption seekers; moreover, their reliance on their faith was mainstream, not fringe. ${ }^{28}$ Importantly, similar to today's exemption seekers, the religious objectors to the CRA bristled when they were characterized as bigots; they, too, considered their religiously-based opposition to the CRA honorable, right, and just. ${ }^{29}$ As Michael Kent Curtis notes:

Slavery, racial discrimination and segregation, and opposition to women's rights were all supported by strong religious arguments bolstered by citations to the Bible. As scholarly work has shown, these religious views were deeply held by many people. That Professor [Robin Fretwell] Wilson finds it impossible to marshal religious arguments for segregation is, to a great degree, a tribute to the success of the Civil Rights Movement and civil rights laws, generally without exemptions for religious objectors.

${ }^{27}$ See Shannon Gilreath \& Arley Ward, Same-Sex Marriage, Religious Accommodation, and the Race Analogy, 41 VT. L. REV. 237, 261, 278 (2016).

${ }^{28}$ MCClain, Who's the Bigot?, supra note 10, at 105, 126.

${ }^{29}$ McClain, Stateways, supra note 24, at 894-95; MCClAIN, WhO'S тне BigOT?, supra note 10, at 8, 117; Randall Kennedy, Marriage and the Struggle for Gay, Lesbian, and Black Liberation, 2005 UTAH L. REV. 781, 791 (2005); James M. Oleske, Jr., The Evolution of Accommodations: Comparing the Unequal Treatment of Religious Objections to Interracial and Same-Sex Marriages, 50 HARV. C.R.-C.L. L. REV. 99, 107-08 (2015). 
Not only could religious arguments for segregation be marshaled, they were marshaled. ${ }^{30}$

It was not just clergy who opposed integration on religious grounds; leading Senators from both sides of the aisle, including Robert Byrd and Strom Thurmond made such arguments on the Senate floor and their sentiments were shared by "educators, 'housewives, sorority sisters, and Rotarians...." 31 In 1963, thenPresident Truman stated that "he did not believe white persons should marry Negroes ... [and] that racial intermarriage ran counter to teachings of the Bible." ${ }^{32}$

Fairly understood, the 1960s exemption seekers espoused views which, though viewed by most people today as offensive, were endorsed by leaders of both major political parties, and which enjoyed a regrettable breadth of acceptance and respect that Americans today might prefer to forget. ${ }^{33}$ The "complete lack of . . . deference" given to opponents of interracial marriage in the 1960 s and the relatively greater deference given

${ }^{30}$ Michael Kent Curtis, A Unique Religious Exemption from Antidiscrimination Laws in the Case of Gays? Putting the Call for Those Who Discriminate Against Married or Marrying Gays in Context, 47 WAKE FOREST L. REV. 173, 187-88 (2012) (citations omitted); see also MCClAin, WHO'S THE Bigot?, supra note 10, at 126, 203.

${ }^{31}$ Gilreath \& Ward, supra note 27, at 262 (alteration in original) (citations omitted).

${ }^{32}$ Oleske, supra note 29, at 100 (quoting Truman Opposes Biracial Marriage, N.Y. Times, Sept. 12, 1963, p. 30).

${ }^{33}$ See McClain, Who's the Bigot?, supra note 10 , at 126 (noting that "religious beliefs about segregation were not 'fringe' in the mid-1960s and were sincerely and widely held"). 
to today's objectors to same-sex marriage "cannot be explained by the extent of contemporary societal support of the respective practices." ${ }^{4}$ Thus, those who in the 1960s opposed racial equality and integration "are entitled to the same presumption of sincerity as current opponents of gay equality. Many believed the religious argument against integration and interracial marriage, just as many people believe the religious arguments against gay equality and liberty." 35

\section{Courts Need Not Assess the Norma- tive Character of Religious Beliefs}

Both opponents of the CRA in the 1960s and today's exemption seekers ground their positions in the

${ }^{34}$ Olekse, supra note 29, at 102, 107 ("According to Gallup, public support of interracial marriage in the 1950s and 1960s was considerably lower than support for same-sex marriage in the 1990s and 2000s.") (citing Jeffrey M. Jones, Record-High 86\% Approve of Black-White Marriages, GaLluP (Sept. 12, 2011), http://www.gallup.com/poll/149390/record-high-approve-blackwhite-marriages.aspx, archived at http://perma.cc/HN22-D5J2 (reporting that public approval of interracial marriage was at just $4 \%$ in 1958 and 20\% in 1968), in comparison with Frank Newport, For First Time, Majority of Americans Favor Legal Gay Marriage, GALLUP (May 20, 2011), http:// www.gallup.com/poll/147662/firsttime-majority-americans-favor-legal-gay-marriage.aspx, archived at http://perma.cc/Y533-7CNC (reporting that support for samesex marriage was $27 \%$ in $1996,42 \%$ in 2004, and $53 \%$ in 2011)).

${ }^{35}$ Curtis, supra note 30, at 191-92; see also Ball, supra note 3, at 241-42; Margaret M. Russell, Lesbian, Gay and Bisexual Rights and "The Civil Rights Agenda", 1 AFR.-AM. L. \& POL'Y REP. 33, 44 (1994); Mark Strasser, Public Policy, Same-Sex Marriage, and Exemptions for Matters of Conscience, 12 FLA. COASTAL L. REV. 135, 139-40 (2010). 
same source: their faith. ${ }^{36}$ The normative characterizations of exemption seekers' reasons for seeking a religious exemption, whether cast as prejudiced or honorable, is inconsequential because courts often take at face value sincerely held religious beliefs, and do so without attaching normative judgments as to whether the asserted belief is "prejudiced" or "honorable." 37

This approach is correct on many levels. As a normative, pragmatic matter, such determinations are beyond judicial competence, thus rendering courts "illequipped" to make such inquiries. ${ }^{38}$ And as a legal matter, courts decline to look behind a sincerely held religious belief. ${ }^{39} \mathrm{As}$ a result, "courts have been reluctant to interpret theologies ... because [they] lack competence on such matters and because they must guarantee government neutrality with respect to religions." ${ }^{40}$ Simply put, "[c]ourts are not arbiters of

${ }^{36}$ See Curtis, supra note 30, at 178; Kennedy, supra note 29, at 783; McClain, Stateways, supra note 24, at 916-18.

${ }^{37}$ See Paul Baker, Note, Religious Exemptions and the Vocational Dimension of Work, 119 CoLUM. L. REV. 169, 171 (2019).

${ }^{38}$ Samuel J. Levine, Rethinking the Supreme Court's HandsOff Approach to Questions of Religious Practice and Belief, 25 FORDHAM URB. L. J. 85, 86 (1997) (citation omitted).

${ }^{39}$ Id. at 86 n.3 (citing United States v. Lee, 455 U.S. 252, 263 $\mathrm{n} .2$ (1982) (Stevens, J., concurring) and County of Allegheny $v$. $A C L U, 492$ U.S. 573, 678 (1989) (Kennedy, J., concurring in part and dissenting in part) and Lyng $v$. Nw. Indian Cemetery, 485 U.S. 439, 457-58 (1987)).

${ }^{40}$ Nelson Tebbe, Reply: Conscience and Equality, 31 J. C.R. \& ECON. DEV. 1, 33 (2018). 
scriptural interpretation." ${ }^{41}$ This has been true in religious exemption cases involving sexual orientation discrimination as well as cases involving race-based discrimination. ${ }^{42}$

It would be problematic to try to distinguish between religious grounds for a sexual orientation exemption and one for a racial exemption because attempts to make those distinctions "contain unavoidable assessments of the reasonableness of the two sets of religious views." ${ }^{43}$ Attempts to distinguish between these two positions "fail from the beginning because they are grounded in the notion that some religious views are more reasonable than others." ${ }^{44}$

This "reluctance of courts to second guess an individual's religious beliefs" 45 shows the strength of the race analogy because it insulates the religious beliefs of exemption seekers from normative characterization by the law as either "prejudiced" or "honorable." ${ }^{46} \mathrm{Be}-$ cause courts must not look behind the "correctness" of sincerely held asserted religious beliefs, they must likewise reject the claim by exemption seekers that courts can classify religious beliefs as "honorable" or

${ }^{41}$ Thomas v. Review Bd. of the Indiana Emp't Sec. Div., 450 U.S. 707, 716 (1981).

${ }^{42}$ See McClain, Who's the Bigot?, supra note 10, at 188.

${ }^{43}$ Ball, supra note 3 , at 240.

${ }^{44} \mathrm{Id}$. at 241.

45 Baker, supra note 37, at 199.

${ }^{46}$ See McClain, Who's the Bigot?, supra note 10, at 196 ("A court does not inquire into whether such sincere religious beliefs are reasonable or mistaken."). 
"bigoted," and then make substantive determinations on claims for religious exemptions based on such impermissible normative characterizations. Today's exemption seekers would improperly "require[] the state to leave its perch of neutrality among religions because the position involves an assessment of which claims of conscience are correct." 47 As such, "the suggestion that the same [religiously-based] arguments cannot be offered against recognizing the different kinds of marriages [interracial or same-sex] is at best irrelevant." 48

Thus, even if it is factually true that public accommodation like CSS "who turn their backs on same sex marriage on religious grounds have no evil in their hearts, in the overwhelming majority of cases," 49 that fact would not be relevant given the plain language of the FPO proscribing discriminatory conduct based on race or sexual orientation without any hierarchy. ${ }^{50}$ Thus, the debate over the intentions of today's exemption seekers is a detour from the merits of the legal questions and a distraction from meaningful consideration of the race analogy and the applicability of Piggie Park.

${ }^{47} I d$.

${ }^{48}$ Id.; see also Strasser, supra note 35, at 141.

${ }^{49}$ Lawrence G. Sager \& Nelson Tebbe, The Reality Principle, 34 Const. Comment. 171, 189 (2019).

50 MCClain, Who's the Bigot?, supra note 10 , at 190 . Notably, the FPO regulates only conduct, not belief. 
Indeed, this Court's obligation to accept CSS's religious beliefs without judgments as to their correctness or reasonableness defeats arguments that Piggie Park is distinguishable. When this Court agreed with the lower court's description of the BBQ joint owner's defense based on his religious belief as "patently frivolous," "51 it was not making a normative judgment about the content of that belief. ${ }^{52}$ That type of moral and normative characterization of a litigant's religious belief is outside the competence of judges and unconstitutional under the First Amendment. This Court might have been commenting on the notion that a business entity could hold a religious belief, something foreign to 1960s Free Exercise jurisprudence, ${ }^{53}$ but which has recently been recognized by this Court in Burwell $v$. Hobby Lobby Stores, Inc. ${ }^{54}$ under which "courts would be compelled to entertain the [BBQ] chain's claim for exemption." 55 Or the Court might well have been commenting that a religious objection as a defense to the nondiscrimination law challenged there was patently frivolous. In any event, neither the Fourth Circuit nor this Court expressed a judgment about the correctness of the religious belief in Piggie Park. As such, Piggie

${ }^{51}$ Piggie Park, 377 F.2d at 437 (Winter, J., concurring).

${ }^{52}$ See Elizabeth Sepper, Free Exercise Lochnerism, 115 CoLuM. L. REV. 1453, 1517 (2015) [hereinafter Sepper, Lochnerism].

${ }^{53}$ See id.

${ }^{54} 573$ U.S. 682, 707 (2014).

${ }^{55}$ Sepper, Lochnerism, supra note 52, at 1517; see also Elizabeth Sepper, Gays in the Moralized Marketplace, 7 ALA. C.R. \& C.L. L. REV. 129, 130, 133-36 (2015) (citing Piggie Park, 390 U.S. at 402 n.5 and United States v. Lee, 455 U.S. 252 (1982)). 
Park cannot be distinguished as involving an incorrect or improper religious belief, and clearly not by a litigant making the constitutionally irrelevant argument that its religious belief is more virtuous than other beliefs to which it could be compared.

Accordingly, while today's exemption seekers may "bristle at the notion that religiously-based resistance to racial integration is of any relevance to present-day controversies[,]"56 whether they are similar or dissimilar to the opponents of the CRA in the 1960s is irrelevant. The fact that both groups base their claims on religious beliefs is the relevant comparison, making Piggie Park and the race analogy applicable here, as Masterpiece Cakeshop recognized. ${ }^{57}$ It is thus important to emphasize that "the mere step of drawing analogies between past and present forms of discrimination to point out how, over time, new insights and evolving understandings have led to recognition that such treatment is unjustified"-as is done when citing Piggie Park in this case- "is not a charge of bigotry." 58 It is equally important to stress that when the City of Philadelphia compares the religious exemption sought here by CSS to race discrimination, this comparison should be not be treated as shorthand for anti-religion

${ }^{56}$ McClain, Stateways, supra note 24, at 925.

${ }^{57}$ Masterpiece Cakeshop, 138 S. Ct. at 1727.

${ }^{58}$ MCClain, Who's THE Bigot?, supra note 10, at 209; see also id. at 201 ("[O]ne can concede religious sincerity while upholding the legitimacy of state anti-discrimination laws."). 
hostility by the City-a point the Court's citation to Piggie Park in Masterpiece Cakeshop underscores. ${ }^{59}$

\section{Equal Protection Tiers of Scrutiny are Irrel- evant to the Question of Religious Exemp- tions from Antidiscrimination Laws}

Although the sexual orientation religious exemption cases involve statutory protections, today's exemption seekers invoke the constitutional tiers of scrutiny to try to persuade courts to reject the race analogy. For example, in briefs and argument in Masterpiece Cakeshop, the baker and his amici supported their general argument that race differs from sexual orientation by arguing that race receives strict scrutiny while sexual orientation receives rational basis review. ${ }^{60}$ Counsel for the baker made a similar claim at

${ }^{59}$ Masterpiece Cakeshop, 138 S. Ct. at 1727 ("[W]hile ... religious and philosophical objections are protected, it is a general rule that such objections do not allow business owners and other actors in the economy and in society to deny protected persons equal access to goods and services under a neutral and generally applicable public accommodations law.").

${ }^{60}$ See Reply Brief for Petitioner at 15, Masterpiece Cakeshop v. Colo. Civil Rights Comm'n, 138 S. Ct. 1719 (2018) (No. 16-111), 2017 WL 5644420, at*15; Transcript, supra note 6, at 20:8-21:20, 22:1-23:6; see also Brief for Lawyers' Committee for Civil Rights Under Law, Asian American Legal Defense and Education Fund, Center for Constitutional Rights, Color of Change, the Leadership Conference of Civil and Human Rights, National Action Network, National Association for the Advancement of Colored People, National Urban League and Southern Poverty Law Center as Amici Curiae Supporting Respondents at 18, Masterpiece Cakeshop, Ltd. v. Colo. Civil Rights Comm'n, 138 S. Ct. 1719 (2018) (No. 16111), 2017 WL 5127306, at*18 [hereinafter Brief for Lawyers' 
the Masterpiece Cakeshop oral argument. ${ }^{61}$ Similarly, scholars supporting religious exemptions contend that the race analogy improperly compares "apples and oranges" - the notion that the racial civil rights movement, which arose from slavery, is simply not

Committee for Civil Rights Under Law]. The United States, appearing as amici in support of the baker, argued that "laws targeting race-based discrimination may survive heightened First Amendment scrutiny" because "a State's 'fundamental, overriding interest' in eliminating private racial discrimination ... may justify even those applications of a public accommodation law that infringe on First Amendment freedoms." Brief for the United States as Amicus Curiae Supporting Petitioners at 32, Masterpiece Cakeshop, Ltd. v. Colo. Civil Rights Comm'n, 138 S. Ct. 1719 (2018) (No. 16-111), 2017 WL 4004530, at *32 (citation omitted). The United States then argued that that same public accommodation law should face a different fate when sexual orientation discrimination is at issue: "The Court has not similarly held that classifications based on sexual orientation are subject to strict scrutiny or that eradicating private individuals' opposition to same-sex marriage is a uniquely compelling interest." Id.

${ }^{61}$ In response to Justice Kagan's question, "[s]ame case or not the same case, if your client instead objected to an interracial marriage?", counsel for the baker responded: "I think race is different for two reasons: one, we know that that objection would be based to who the person is, rather than what the message is. And, second, even if that were not the case, the Court could find a compelling interest in the race inquiry. ..." Transcript, supra note 6 , at 22:1-23:6. In response to Justice Sotomayor's question, "is your theory that ... public accommodation laws cannot trump free speech or free-exercise claims in protecting against race discrimination?", the baker's attorney responded: "That is not my theory. That would be an objection to the person and the Court may find a compelling interest in that." $I d$. at 21:12-20. These references to a compelling interest are, of course, references to the argument that race gets strict scrutiny and, according to the argument, sexual orientation does not. 
comparable to the LGBT-rights movement, as illustrated by what they contend are differing levels of equal protection scrutiny. ${ }^{62}$

Significantly, this Court has not yet determined the level of equal protection scrutiny afforded to sexual orientation, although its recent decision in Bostock $v$. Clayton County suggests that sexual orientation, like sex, is subject to intermediate scrutiny ${ }^{63}$ Moreover, the Ninth Circuit and Second Circuit have held that sexual orientation is subject to heightened scrutiny. ${ }^{64}$ Yet putting all of that aside, Petitioners' argument nonetheless fails.

As an initial matter, this argument is out of place where the statute at issue-a public accommodation law-does not classify based on race, or on any protected classification. The law declares that the prohibited conduct-discrimination in the marketplace-is prohibited vis-à-vis all protected individuals (race, sex, religion, sexual orientation, etc.); it is a neutral law of general applicability that even-handedly applies to all places of public accommodation. Moreover, CSS does not challenge the FPO under the Equal Protection Clause, the provision most readily associated with the

62 Wardle \& Oliphant, supra note 25, at 144-45.

63 See Bostock, 140 S. Ct. at 1778 (Alito, J., dissenting).

64 E.g., Karnoski v. Trump, 926 F.3d 1180, 1200-01 (9th Cir. 2019); Latta v. Otter, 771 F.3d 456, 468 (9th Cir. 2014); SmithKline Beecham Corp. v. Abbott Labs, 740 F.3d 471, 480-81 (9th Cir. 2014); Windsor v. United States, 699 F.3d 169, 180-85 (2d Cir. 2012), aff'd, 570 U.S. 744 (2013). 
argument that "race gets strict scrutiny, but sexual orientation gets rational basis."

Exemption seekers' arguments on this front take two forms. First, because they contend sexual orientation should be subject to rational basis review, ${ }^{65}$ cities like Philadelphia do not have a compelling interest in protecting against sexual orientation discrimination in the marketplace. In contrast, the argument proceeds, because race gets strict scrutiny, cities like Philadelphia do have a compelling interest in protecting against racial discrimination in the marketplace. ${ }^{66}$

This argument turns antidiscrimination law on its head and contradicts this Court's precedent declaring that protecting against discrimination in public accommodation is a compelling state interest. ${ }^{67}$ As a result, when a statute's plain language declares that both race and sexual orientation are deserving of the protection of a public accommodation law, there is necessarily a compelling state interest in supporting every application of the antidiscrimination statute.

${ }^{65}$ But see Bostock, 140 S. Ct. at 1743 (holding that sexual orientation discrimination is sex discrimination under Title VII); id. at 1783 (Alito, J., dissenting); Karnoski, 926 F.3d at 1200-01; Latta, 771 F.3d at 468; SmithKline Beecham Corp., 740 F.3d at 480-81; Windsor, 99 F.3d at 180-85.

${ }^{66}$ See Wardle \& Oliphant, supra note 25, at 144-45.

${ }^{67}$ See Jaycees, 468 U.S. at 624 (noting that "eliminating discrimination and assuring its citizens equal access to publicly available goods and services ... plainly serves compelling state interests of the highest order."). 
Masterpiece Cakeshop suggests that exemption seekers' argument concerning the level of scrutiny should not carry the day. The Court wrote that it was "unexceptional" that states can protect LGBT people through public accommodation law, as Colorado did there. ${ }^{68}$ The Court's "matter-of-fact" assessment of state antidiscrimination laws "is an important implicit rejection of . . . the argument that . . the state's interest in prohibiting race discrimination is far more compelling then addressing other forms of discrimination[,]" such as sexual orientation discrimination. ${ }^{69}$

Moreover, Bostock's holding that sexual orientation discrimination is per se sex discrimination under Title VII ${ }^{70}$ has "far-reaching consequences" that spill over into constitutional law. ${ }^{71}$ Sex-based discrimination is subject to intermediate scrutiny under the Equal Protection Clause. ${ }^{72}$ Thus, "[b]y equating discrimination because of sexual orientation or gender identity with discrimination because of sex, the Court's decision will be cited as a ground for subjecting all three forms of discrimination to the same exacting

68138 S. Ct. at 1728.

69 MCClain, Who's the Bigot?, supra note 10, at 207; see also Romer, 517 U.S. at 627-28 (noting with approval "modern anti-discrimination laws" that "go[] well beyond the entities covered by the common law" by "enumerating the groups or persons within their ambit of protection"-such as LGBT people- "to make the duty not to discriminate concrete and to provide guidance for those who must comply.").

${ }^{70}$ Bostock, 140 S. Ct. at 1742.

${ }^{71} \mathrm{Id}$. at 1778 (Alito, J., dissenting).

${ }^{72}$ See, e.g., U.S. v. Virginia, 518 U.S. 515, 532-34 (1996). 
standard of review." 73 The consequence of having the same Equal Protection standard for sexual orientation and sex defeats exemption seekers' argument that race is inapposite because race gets strict scrutiny while sexual orientation only gets rational basis review.

In fact, in Roberts $v$. United States Jaycees, the Court held that a public accommodation law that protected against sex discrimination served a compelling state interest, even though sex-based classifications received only intermediate constitutional scrutiny. ${ }^{74}$ After Bostock, that same conclusion should result with regard to public accommodation laws that protect against sexual orientation discrimination. Moreover, the Court has suggested that a state legislature had the authority to serve its interest in prohibiting sexual orientation discrimination in public accommodation law, ${ }^{75}$ even if sexual orientation received only rational basis-or, more likely after Bostock, intermediate scrutiny-in equal protection inquiries. Thus, to accept the exemption seekers' argument about strict scrutiny-to analyze religious exemption claims differently depending on the individual relying on statutory protection based on an equal protection doctrine that is not implicated-is to defy the Court's declaration that public accommodation laws serve compelling government

${ }^{73}$ Bostock, 140 S. Ct. at 1783 (Alito, J., dissenting).

${ }^{74}$ See Jaycees, 468 U.S. at 623.

${ }^{75}$ See Hurley v. Irish-Am. Gay, Lesbian \& Bisexual Group of Bos., 515 U.S. 557, 572 (1995). 
interests, even where classes that do not receive strict scrutiny under equal protection are at issue. ${ }^{76}$

A second variation of this argument appears to be that the First Amendment claims being made by the exemption seekers requires strict scrutiny. That fact, coupled with the fact that race receives strict scrutiny, is urged as support for the argument that "race is just different." 77 Thus, the argument seems to be that because the free exercise claims and race both get strict scrutiny, the public accommodation law is not narrowly tailored in a way to survive the double strict scrutiny inquiry. ${ }^{78}$ However, because public accommodation laws are neutral laws of general applicability, they generally are considered under the rational basis test rather than the strict scrutiny test when challenged under the First Amendment. ${ }^{79}$ Indeed, when the Court

${ }^{76}$ See generally Brief for Lawyers' Committee for Civil Rights Under Law, supra note 60, at*18-19; Deborah A. Widiss, Intimate Liberties and Antidiscrimination Law, 97 B.U. L. REv. 2083, 2128 (2017) ("The assumption that protection against marital status discrimination is less compelling than protection against discrimination on the basis of race or sex is deeply problematic.").

77 See Brief for Freedom of Speech Scholars as Amici Curiae Supporting Respondents at 16 Masterpiece Cakeshop, Ltd.v. Colo. Civil Rights Comm'n, 138 S. Ct. 1719 (2018) (No. 16-111), 2017 WL $4876116, * 16$.

${ }^{78}$ See id.

${ }^{79}$ See Employment Division v. Smith, 494 U.S. 872, 879 (1990); see Brief of Amicus Curiae NAACP Legal Defense \& Educational Fund, Inc. in Support of Respondents, Masterpiece Cakeshop, Ltd. v. Colo. Civil Rights Comm'n, 138 S. Ct. 1719 (2018) (No. 16-111), 2017 WL 5127302 [hereinafter Brief of NAACP Legal Defense \& Educational Fund]. 
has "considered and rejected religious exemptions in the past, those precedents are not limited to the context of racial discrimination simply because they originally arose in that context." $\$ 0$

In sum, these arguments seeking to treat exemption claims against various antidiscrimination statutes as receiving radically different constitutional analyses are flawed. The arguments conflate a government's compelling interest to combat discrimination in public accommodation with the level of scrutiny that applies in an equal protection claim. ${ }^{81}$ It is therefore "irrelevant whether government-sponsored sexual orientation discrimination receives the same scrutiny as government-sponsored racial discrimination." ${ }^{22}$ That is because the state interest in preventing discrimination is the appropriate interest to consider in evaluating any constitutional challenge to a public accommodation law, rather than the constitutional scrutiny that is afforded to governmental discrimination against those groups protected by the public accommodation law. ${ }^{83}$

${ }^{80}$ Brief of NAACP Legal Defense \& Educational Fund, supra note 79 , at 16 .

${ }^{81}$ See id. at 19; accord David B. Cruz, Piety and Prejudice: Free Exercise Exemption from Laws Prohibiting Sexual Orientation Discrimination, 69 N.Y.U. L. REV. 1176, 1186-89 \& n.63 (1994).

${ }^{82}$ Brief for Lawyers' Committee for Civil Rights Under Law, supra note 60 , at 19.

${ }^{83}$ Brief of Amicus Curiae NAACP Legal Defense \& Educational Fund, supra note 79, at *16-*19 and n.18. 


\section{The Race Analogy Is Useful in Resolving This Case}

This Court can and should rely on the race analogy in resolving this case, but without recourse to distracting invocations of whether a religious belief is "honorable" or grounded in "animus" because courts do not normatively interrogate religious beliefs before determining the applicability of antidiscrimination statutes. Proceeding from this understanding, the plain language of the FPO (and similar state public accommodation laws) make the analogy to race and to Piggie Park appropriate, as this Court recognized in Masterpiece Cakeshop. This Court's decision in Bostock adds force to the race analogy by its clear directive to privilege the plain language of a statute. ${ }^{84}$ The plain language of the FPO unambiguously lists sexual orientation alongside race as equally within the statute's protections. The discriminatory conduct proscribed by the FPO is equally prohibited regardless of whether a Black, heterosexual couple is turned away from a restaurant or whether a white, same-sex couple is turned away by CSS. Because the statute's plain language is a straightforward command not to discriminate that creates no hierarchy of protections, discriminating based on sexual orientation is "just as intolerable as discrimination directed toward race, national origin, or religion." "That intolerance of discrimination is not

${ }^{84}$ Bostock, 140 S. Ct. at 1749.

${ }^{85}$ Elane Photography v. Willock, 309 P.3d 53, 79-80 (N.M. 2013) (Bosson, J., concurring) (rejecting a wedding photographer's request for a religious exemption from the New Mexico 
unreasonable and unwarranted." ${ }^{\prime 6}$ As in Bostock, because "the meaning of the statute's terms is plain, [a court's] job is at an end." 87

Moreover, the principle behind antidiscrimination laws supports use of the race analogy in sexual orientation religious exemption cases. The goal of public accommodation laws is to preclude the perpetuation of unequal status hierarchies through discrimination in the marketplace. While all individuals are protected from the specified forms of discrimination, including LGBT people and people of color, the groups in the current dispute and in the case law are similarly situated: the statute's plain language protects these groups who are vulnerable to invidious discrimination in the public square. ${ }^{88}$ Although the historical, cultural, and political reasons for vulnerability to discrimination in the marketplace vary, the harms against which the statute seeks to protect is similar enough to support the analogy in this context-the stigmatic and economic harm of discrimination in public accommodation. ${ }^{89}$

public accommodation law that would allow the photographer to turn away same-sex couples).

${ }^{86}$ MCClain, Who's the Bigot?, supra note 10, at 154.

${ }^{87}$ Bostock, 140 S. Ct. at 1749.

${ }^{88}$ Sager \& Tebbe, supra note 49, at 173 ("The central aim of civil rights law is to protect members of vulnerable groups from the harms of structural injustice; that vital project would be undermined by a broad carve out for religious dissent.").

${ }^{89}$ See Russell, supra note 35, at 44; Roberts, 468 U.S. at 625. 
Because public accommodation law "does not take sides in a purported culture war" ${ }^{90}$ but instead "stipulates what citizens who are divided on questions of profound importance nonetheless owe to each other in order to live together as equals in our political community[,]"91 a statute's unambiguous inclusion of both race and sexual orientation in a civil rights law renders analogies to race proper. The Court itself has declared that a state legislature's decision to include LGBT people within its laws is a decision that the Court and the Constitution should recognize and uphold. ${ }^{92}$

In fact, this Court has analogized to race when analyzing a sex discrimination claim under federal antidiscrimination law that included both race and sex as protected classes. In City of Los Angeles v. Manhart, the Court faced a class-action challenge made by women alleging that the Department of Water and Power's requirement that female employees make larger contributions to its pension fund than male employees violated Title VII. ${ }^{93}$ While Title VII prohibits discrimination in employment and the FPO prohibits discrimination in public accommodation, both

${ }^{90}$ Sager \& Tebbe, supra note 49, at 173.

${ }^{91}$ Id. at $173-74$.

${ }^{92}$ See Windsor, 570 U.S. at 768 (emphasizing that New York's recognition of same-sex marriages was a proper use of its "historic and essential authority to define the marital relation in this way" and that this legislative decision "enhanced the recognition, dignity, and protection of the class in their own community").

93435 U.S. 702, 704-05 (1978). 
statutes similarly enumerate numerous forms of discrimination addressed by their protections-"race, color, religion, sex, or national origin" ${ }^{94}$ for Title VII and "race, ethnicity, color, sex, sexual orientation, gender identity, religion, national origin, ancestry, disability, marital status, familial status, or domestic or sexual violence victim status" ${ }^{\prime 95}$ for the FPO.

The Manhart Court used the race analogy to support its decision that the city's requirement was sexbased discrimination in violation of Title VII: "Congress has decided that classifications based on sex, like those based on national origin or race, are unlawful." ${ }^{\text {96 }}$ Because the Court found that the city's pension rule would not be permissible as to race, it reasoned by analogy that it was not permissible as to sex. ${ }^{97}$ That the Court was comfortable with finding what might be termed "statutory sameness" between race and sex should dictate that the "statutory sameness" between sexual orientation and race is compelling in the present case. This is particularly true after Bostock: Because bans on sex-based discrimination ban sexual orientation-based discrimination, and because the Court analogizes race to sex, the Court therefore should analogize race to sexual orientation. After Bostock, then, there is a clear through-line from the acceptance of the sex-race

9442 U.S.C. $\S 2000 \mathrm{e}-2(\mathrm{a})(1)$.

${ }^{95}$ Philadelphia Code $§ 9-1106$.

96435 U.S. at 709.

${ }^{97} \mathrm{Id}$. ("But a statute that was designed to make race irrelevant in the employment market could not reasonably be construed to permit a take-home-pay differential based on a racial classification.") (citation omitted). 
analogy in both Manhart and Jaycees, to the subsuming of sexual orientation discrimination under sex discrimination in Bostock, to the sexual orientation-race analogy supporting the Respondents here.

The race analogy is thus appropriate in the context of public accommodation statutes. To allow any other result would create incoherence in the law, disregard the FPO's plain language, and send a normative message that discrimination against LGBT consumers is natural, normal, and acceptable. ${ }^{98}$

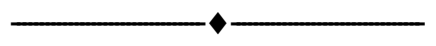

\section{CONCLUSION}

This country and this Court have considered and rejected claims for religious exemptions from public accommodation laws in similar contexts to the claims asserted by today's exemption seekers. We do not need "new and expansive accommodations that depart significantly from the ways in which the nation has in the past accommodated liberty considerations while seeking to attain equality objectives in the context of race and gender." ${ }^{\prime 99}$ This Court should look to what worked historically when similar challenges to antidiscrimination laws-in the context of race and sex-have been raised. ${ }^{100}$ Analogizing to race in the present dispute

${ }^{98}$ See Tebbe, supra note 40, at 61-62.

${ }^{99}$ Ball, supra note 3 , at 238.

${ }^{100} \mathrm{Id}$. at 245 ("In other words, there is no need to reinvent the exemption wheel. The bottom line is this: we should be suspicious of the contention that the push for LGBT rights, in particular as it relates to marriage equality, constitutes a unique threat to religious liberty that requires significant departures from the 
requires no improper governmental assessment of religious beliefs, just as courts made no such assessment in the 1960s. The race analogy, including an analogy to Piggie Park, should be used today and would not require an inquiry into Petitioners' sincerely held religious beliefs.

Kyle C. Velte

Associate Professor

Counsel of Record

UNIVERSITY OF KANSAS

SCHOOL OF LAW

1535 W. 15th St.

Lawrence, KS 66045

(720) 648-9266

kvelte@ku.edu

DAVID B. CRUZ

Newton Professor of

Constitutional Law

UNIVERSITY OF SOUTHERN

CALIFORNIA

GOULD SCHOOL OF LAW

699 Exposition Blvd.

Los Angeles, CA 90089

MiCHAEL J. HigdoN

Associate Dean for Faculty

Development and

Professor of Law

University OF TENNESSEE

COLLEGE OF LAW

1505 W. Cumberland Avenue

Knoxville, TN 37996
Respectfully submitted,

ClifFord S. DAVIDSON

SNELL \& WiLMER

One Centerpointe Dr.

Lake Oswego, OR 97035

503-624-6800

csdavidson@swlaw.com

Kelly H. Dove

SNELL \& WiLMER

3883 Howard Hughes Pkwy., Suite 1100

Las Vegas, NV 89169

702-784-5286

kdove@swlaw.com

SHIRLEY LIN

Acting Assistant Professor

NEW YORK UNIVERSITY

SCHOOL OF LAW

40 Washington Sq. South

New York, NY 10012

ways in which American antidiscrimination law has accommodated religious liberty in the past."). 
ANTHONY MichaEL KREIS

Assistant Professor GeORgIA State UnIVERSITY COLLEGE OF LAW

85 Park Place NE, Room 314

Atlanta, GA 30303
LINDA C. MCCLAIN Robert Kent Professor of Law BOSTON UNIVERSITY

SCHOOL OF LAW

765 Commonwealth Avenue

Boston, MA 02215 